\title{
Key Directions and Problems of Efficiency Assessment for State Support of Agriculture
}

\author{
Shishkina N.V.* \\ Chair of Economics and global economy \\ Voronezh state agrarian university \\ Voronezh, Russia \\ natalia.schischkina@yandex.ru
}

\author{
Sabetova T.V. \\ Chair of Management and marketing in AIC \\ Voronezh state agrarian university \\ Voronezh, Russia \\ tsabetova@mail.ru
}

\author{
Apyrbaev G.A. \\ Chair of Economics and global economy \\ Voronezh state agrarian university \\ Voronezh, Russia \\ scyfall@mail.ru
}

\begin{abstract}
The paper substantiates the need for the formation of a set of measures of state support for agriculture. The concepts of "state regulation", "state support", "state assistance" and their goals are considered. The authors highlighted the main parameters of financial support in accordance with the State Program for the Development of Agriculture and the regulation of agricultural products, raw materials and food markets. The article considers the dynamics of the total amount of financial support provided within the State Program and highlights the changes in the composition of its directions at the regional level using the example of the Voronezh region. It is concluded that the set of support directions is constantly changing, and at the regional level, changes occur more often, are distributed relatively evenly in time and, apparently, reflect the current and medium-term needs of the agricultural sector of the region of the Russian Federation. The authors identified three levels of influencing factors upon the decisions in the field of state support for agriculture: the level of national agrarian policy; level of regional agricultural policy; micro level of the needs of individual producers and other entities of the agricultural sector. The article presents the key approaches to assessing the efficiency of the state support for agriculture in accordance with the set goals. The choice of indicators that would allow evaluation of the results of the measures of state support for agriculture is justified.
\end{abstract}

Keywords - state program, state support, efficiency, indicators, results, agrarian policy

\section{INTRODUCTION}

The emerging economic and social situation in agriculture and rural areas, its main challenge, consisting in the urgent need for a transition to the innovative development path, require the formation of a set of measures to support agricultural production and public institutions in rural areas [1]. Zakshevskaya, Kuksin and Stashevsky [2] point to this complex as an integral and most important part of the general regulatory impact of the state on the agricultural sector of the economy.
In the papers written by economists, the concepts of "state regulation", "state support", and "state assistance" are often used as synonyms, or only one of them is used, and the others are abandoned. Gubanova [3] claims that the system of state regulation is the broadest of the listed concepts and includes all kinds of ways of state influence not only on the economy, but also on the whole social life. State assistance is targeted particularly, its sole purpose is to improve the situation of an individual entity, it is used in conditions of threat to this entity, crisis. State support is more likely to be preventive in nature and is aimed not at eliminating, but at preventing crisis phenomena. Moreover, it does not place the subjects in different conditions in terms of competition.

\section{Methods AND PROCEDURE}

The basic rule of state support for agricultural production in various developed countries is that only the degree and forms of intervention are used that, firstly, provide people's employment in agricultural production with the income necessary for normal life, and secondly, that stimulate sustainable economic growth of the efficiency of agricultural enterprises, including labor productivity of farmers [4]. Ultimately, these measures guarantee an equalization of the living standards of the villagers and urban residents employed in other sectors and at the same time guarantee the country's food security [5]. From the experience, these countries have created the conditions for maintaining a high living standard in rural areas, but at the same time, these measures absorb substantial financial resources for agricultural assistance, scooped in other sectors of the economy.

In authors' opinion, another goal seems to be more rational: to provide state support to any industry, including the agricultural one: to provide short- or medium-term assistance in any direction, but with the expectation that then this industry will reach an equilibrium when its sustainable development is already ensured without additional support measures. 
State support for agriculture and related industries, and consequently, to the entire process of implementing the state agrarian policy is carried out in the Russian Federation and the Voronezh region in the framework of the relevant state programs. In general, more than substantial funds have already been allocated in the country as part of the implementation of the State Program for the Development of Agriculture and the regulation of agricultural markets, raw materials and food (Fig.1).

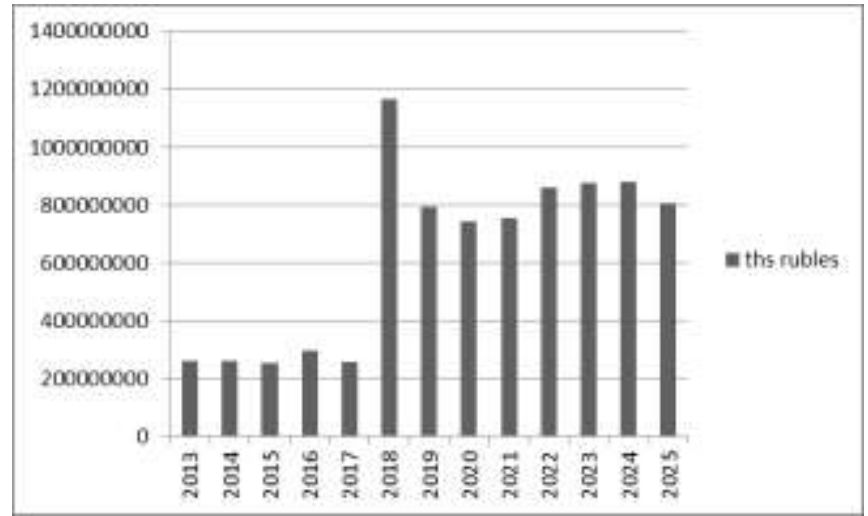

Fig. 1. Parameters of the financial provision for the State Program for the Development of Agriculture and the regulation of agricultural markets, raw materials and food (2020-2022 - in acordance with the Federal budget for 2020 and planned period of 2021-2022; from 2023 - project)

The volume of appropriations increased sharply after the Program's transformation and allocation in its structure of the second stage with new goals. These changes, in our opinion, are associated with a number of positive and negative factors:

- understanding of insufficiency of the financing allocated for the Program implementation in 20132017, proved by the evaluations;

- alteration of the Program goals in different versions of its passport since 2017;

- reorientation of the Program's goals from intrasectoral ones aimed at working within the framework of the national economy to larger ones, involving financial, reproductive, and foreign economic processes.

Thus, during the period of amending the Program, part of the goals that have been present in it since its initial adoption were retained in it as part of the first, now completed stage, from which it should be assumed that they are currently considered to be achieved. This is quite acceptable, especially considering that only the first of three such goals contain specific quantitative indicators in the form of a reference to the Food Security Doctrine, which, however, is approved for each year by the Decree of the President of the Russian Federation, and threshold changes occur in some years for the indicators of food independence. In particular, according to information provided on the information and legal portal Garant.ru, the new doctrine of food security for 2020 contains precisely such changes (Fig. 2).

On the one hand, these changes affected only three product groups out of eleven; on the other hand, the changes in the values themselves cannot be called small: plus $5 \%$ for fish products and plus $10 \%$ for sugar and vegetable oil. Although the Doctrine is currently tightening the interpretation of the term "food independence", in other years reverse processes may occur, both for reasons of expediency and realism [6]. For example, in the draft Decree for 2018, posted on the same portal, the level of self-sufficiency in fruits and berries was declared at a level of at least $70 \%$.

\begin{tabular}{|c|c|c|c|}
\hline & & \multicolumn{2}{|c|}{$\begin{array}{l}\text { threshold values of } \\
\text { food security }\end{array}$} \\
\hline & & Earlier & 2020 \\
\hline \multirow{4}{*}{$\begin{array}{l}\text { है } \\
\text { है } \\
\text { है }\end{array}$} & Sugar & at least $80 \%$ & at least $90 \%$ \\
\hline & Vegetable oil & at least $80 \%$ & at least $90 \%$ \\
\hline & Fish and fish products & at least $80 \%$ & at least $85 \%$ \\
\hline & Grain & \multicolumn{2}{|c|}{ at least $95 \%$} \\
\hline & Meat and meat products & \multicolumn{2}{|c|}{ at least $85 \%$} \\
\hline & Milk and dairy products & \multicolumn{2}{|c|}{ at least $90 \%$} \\
\hline & Potatoes & \multicolumn{2}{|c|}{ at least $95 \%$} \\
\hline 늘 & Cooking salt & \multicolumn{2}{|c|}{ at least $85 \%$} \\
\hline$=$ & Vegetables and gourds: & \multicolumn{2}{|c|}{ at least $90 \%$} \\
\hline & Fruits and berries & \multicolumn{2}{|c|}{ at least $60 \%$} \\
\hline & Crop seeds & \multicolumn{2}{|c|}{ at least $75 \%$} \\
\hline
\end{tabular}

Fig. 2. Changes of the threshold values of the food security in 2020 (compared to earlier versions of 2013 to 2018)

At the regional level, certain shifts are also observed both in the volume of assistance provided and in its directions.

\section{ANALYSIS}

The dynamics of the total volume of financial support provided under the State Program is presented in Figure 3. 


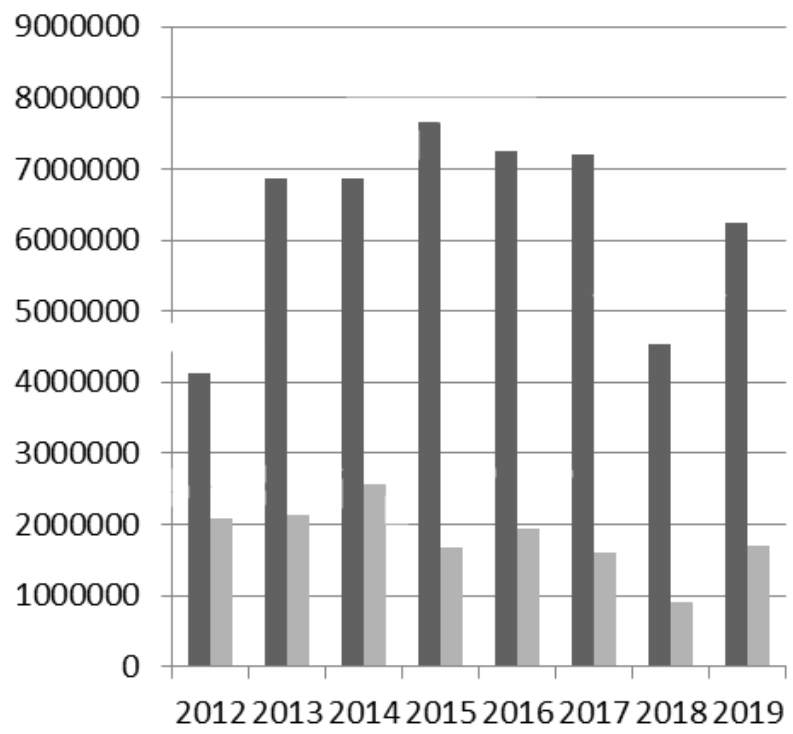

from the federal budget

from the regional budget

Fig. 3. Volume of the provided state support in the Voronezh region under the State Program

In total, the growth in volumes was observed only from 2012 to 2014 , and then stabilization and even a slight gradual reduction took place: from 9.4 billion rubles in 2014 to 8.8 billion rubles in 2017 . In 2018, there was a sharp decline in the volume of allocated financing under the State Program to just 5.4 billion rubles, and in 2019 we are seeing an equally sharp increase - again to almost 8 billion rubles, that is, by $46 \%$ compared to the previous year. However, if we compare 2019 to 2012, we observe an increase of only $28 \%$, and the level of 2013-2017 has not been achieved.

Although the researchers name the reasons for such fluctuations as a variety of factors, in general, the absence of any intelligible trend in itself seems to us to be a negative phenomenon, since it indicates lack of regularity and the impossibility for agricultural producers to rely on certain actions of authorities at different levels.

At the same time, another aspect of support, namely, the distribution of financial expenses between the federal center and the constituent entity of the Russian Federation shows a much more pronounced tendency over the same period (Fig. 4).

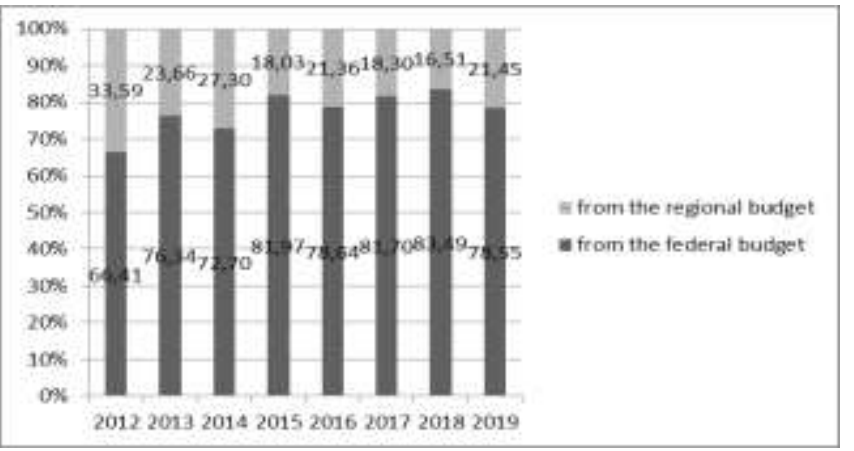

Fig. 4. Shares of finance expenses from the federal budget and the budget of the Voronezh region
Despite quite significant fluctuations over the years, there is still a pronounced trend: the share of the budget of the Voronezh region in the financing of the State program is reduced from $33.59 \%$ in 2012 to $21.45 \%$ in 2019, and the minimum share was observed in 2018 and amounted to only $16.51 \%$.

In the Voronezh region, state support for agriculture is implemented not only within the framework of the State program, but also within the framework of the identified areas of the regional program. Support data for 2017 are not available. However, the dynamics for the remaining years, presented in Figure 5, also indicates a very wide range of fluctuations in funding volumes.

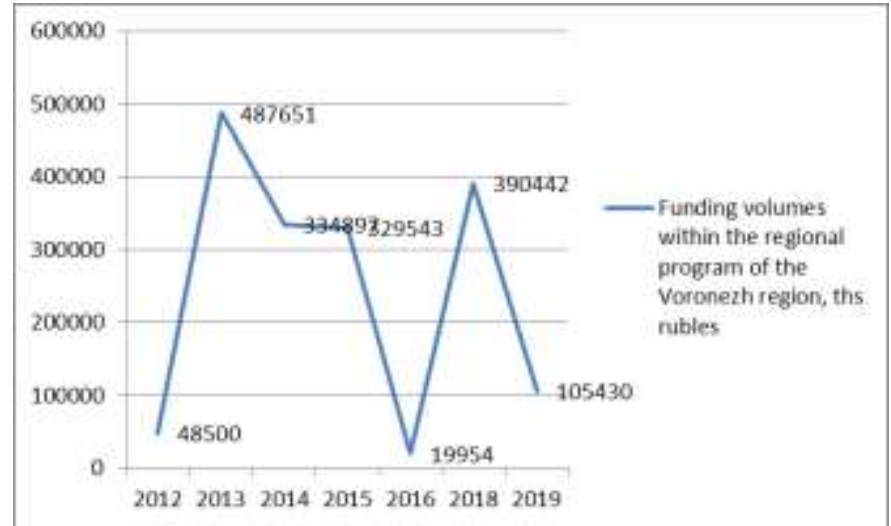

Fig. 5. Dynamics of funding volumes within the regional program of the Voronezh region

The volume of support provided between the years with minimum and maximum funding varied by almost 25 times.

Thus, a preliminary conclusion is drawn about the extreme chronological unevenness of the financial assistance provided. Moreover, at the regional level, the fluctuations are much more significant than at the federal level. We emphasize that a significant part of the funds is transferred to agricultural 
companies according to their own applications, and it requires not only the formation of a certain package of documents, but also the preliminary compliance of the applicant or certain aspects of his activities (for example, of the project requiring support) with a number of conditions. This leads to the conviction that the state and possibilities of the budget have less influence on the support process than the needs of agricultural producers themselves. The needs of the latter in this context are determined by the situation in their current activities, for example, short-term fluctuations in natural, climatic, and macroeconomic conditions, and only in rare cases, by strategic plans for the activities and development of subjects, because the latter, by definition, cannot be so flexible and volatile, as suggested by the observed dynamics.

\section{DISCUSSION}

The stability or, on the contrary, instability and variability of the regional agrarian policy pursued by the authorities, in our opinion, can be visually proved not so much by the dynamics of the indicators of the volumes of support provided to agriculture, but by an analysis of the directions in which such assistance is provided.

Within the framework of the State program, it is extremely important to distribute support by directions, since it illustrates the opinion of state and regional authorities on what subjects and what types of assistance are needed, and therefore, what are the main directions of agricultural development that attract attention the state and its regulatory impact. However, during the observation period, the list of these directions at the level of the Voronezh region underwent certain changes (Table 1).

TABLE I. ALTERATIONS IN THE COMPOSITION OF SUPPORT OF AGRICULTURE IN THE VORONEZH REGION WITHIN THE STATE PROGRAM

\begin{tabular}{|c|c|c|c|c|c|c|c|}
\hline 2012 & 2013 & 2014 & 2015 & 2016 & 2017 & 2018 & 2019 \\
\hline \multicolumn{2}{|c|}{$\begin{array}{l}\text { Social development of } \\
\text { the countryside }\end{array}$} & \multicolumn{4}{|c|}{$\begin{array}{l}\text { Sustainable development of rural areas in } 2014 \text { - } \\
2017 \text { and for the period till } 2020\end{array}$} & \multicolumn{2}{|c|}{$\begin{array}{c}\text { Sustainable development } \\
\text { of rural areas }\end{array}$} \\
\hline \multicolumn{8}{|c|}{$\begin{array}{c}\text { Partial compensation of the insurance expenses of the } \\
\text { agricultural producers }\end{array}$} \\
\hline \multicolumn{5}{|c|}{ Decoupled support for the agricultural producers in crop } & \multirow{4}{*}{\multicolumn{3}{|c|}{$\begin{array}{l}\text { Development of the sectors of agro- } \\
\text { industrial complex (AIC) }\end{array}$}} \\
\hline \multirow{2}{*}{\multicolumn{5}{|c|}{$\begin{array}{r}\text { State support of animal husbandry } \\
\text { State support of cron farming }\end{array}$}} & & & \\
\hline & & & & State support of crop farming & & & \\
\hline \multicolumn{5}{|c|}{$\begin{array}{l}\text { State support of economically viable regional programs } \\
\text { Partial compensation of the interests for loans and credits }\end{array}$} & & & \\
\hline \multicolumn{5}{|c|}{$\begin{array}{c}\text { Technical and technological modernization, innovative } \\
\text { development }\end{array}$} & \multirow{2}{*}{\multicolumn{3}{|c|}{$\begin{array}{c}\text { Stimulation of innovative activities } \\
\text { in AIC }\end{array}$}} \\
\hline \multicolumn{5}{|c|}{$\begin{array}{c}\text { Partial compensation of the direct expenses for creation and } \\
\text { updating of the objects for AIC }\end{array}$} & & & \\
\hline \multicolumn{5}{|c|}{ State support of small business units } & & & \begin{tabular}{|c|} 
Creation of \\
the system for \\
supporting \\
the farmers \\
and \\
development \\
of rural \\
cooperation
\end{tabular} \\
\hline & & Deve & $\mathrm{f}_{1}$ & of & ids in & duri & $4-2020$ \\
\hline
\end{tabular}

The analysis of the support directions within the regional program in the Voronezh region showed the following:

1. In the set of support directions, qualitative development is obvious in the form of increasing the number and variety of subprograms.

2. Support directions include specific sectors, some of which receive supporting for a short period, 3-4 years (beet, quail, rabbit farming), and others for a much longer period (fish farming), for several the decision to start supporting was made quite recently (horse breeding).

3. In some support directions, there are gaps in the period of support (production and purchase of seeds, compensation of costs for the purchase of agricultural machinery).

The unevenness in the system of providing state support for agriculture under the regional program is even more pronounced than under the state program, both in quantitative terms (funding volumes) and in qualitative terms (set of directions).

The general conclusions are proved by all the data demonstrated in this work:

1. State support to agriculture is provided through a wide range of general and specific directions, both within the framework of the state and regional programs.

2. The set of support directions is constantly changing, and if at the state level the bulk of the changes are timed to 2017, that is, to the beginning of the second stage of the implementation of the State program, then at the regional level changes occur more often, are distributed relatively evenly in time and, apparently, reflect current and medium-term needs of the agricultural sector of the region of the Russian Federation.

3. Even within the same direction, the volumes of support from year to year can many-fold or even dozens of times be higher.

4. At the level of the State program, there is a qualitative concentration within the framework of gross directions of support, while at the regional level, on the contrary, the set of directions of support is not being reduced and is constantly changing.

Thus, three levels of the factor influences on the decisions in the field of state support for agriculture become apparent:

- the level of national agrarian policy and available budgetary resources, the main influence of which is directed to a greater degree to the stabilization of quantitative and qualitative characteristics of the support provided, but at the same time relatively weak;

- the level of regional agrarian policy (regional strategic subsystem) and medium-term regional needs and opportunities (operational regional subsystem), the impact of which is much more variable;

- the micro level of the needs of individual producers and other entities of the agricultural sector, the impact of which is sporadic and poorly predictable, but the whole system, in fact, is focused on meeting the needs of this level.

The need for state support of agriculture is explained by a number of reasons [7], and at the same time it is logical to assume that on the basis of these reasons, methodological approaches to assessing the effectiveness of implemented measures can be formed. Consider the main reasons for supporting agriculture based on the work of Minakov and Kuvshinov [8], and highlight the possible approaches to 
assessing the effectiveness of eliminating these causes with the help of state support measures (Table 2).

TABLE II. BASIC APPROACHES TO EVALUATE THE EFFICIENCY OF PUBLIC SUPPORT FOR AGRICULTURE

\begin{tabular}{|c|c|}
\hline Support target & $\begin{array}{c}\text { Approach to the efficiency } \\
\text { assessment }\end{array}$ \\
\hline Provision of national food security & $\begin{array}{l}\text { The level of food market dependence } \\
\text { (independence) on imports }\end{array}$ \\
\hline $\begin{array}{l}\text { Satisfaction of the population's } \\
\text { demand }\end{array}$ & $\begin{array}{l}\text { The indicators of the market } \\
\text { saturation }\end{array}$ \\
\hline $\begin{array}{l}\text { Provision of quality and } \\
\text { environmental purity of food }\end{array}$ & $\begin{array}{l}\text { The share of food in the market not } \\
\text { meeting the safety requirements, } \\
\text { standards and environmental needs }\end{array}$ \\
\hline $\begin{array}{l}\text { Agriculture influence upon macro- } \\
\text { economic situation }\end{array}$ & $\begin{array}{l}\text { The share of agriculture in GDP } \\
\text { (GRP) and in tax revenues of the } \\
\text { budgets }\end{array}$ \\
\hline $\begin{array}{l}\text { Fair distribution of income and profit } \\
\text { among economic players }\end{array}$ & $\begin{array}{l}\text { Wage level in agriculture compared } \\
\text { to the average throughout the } \\
\text { economy [9]; } \\
\text { Profit margin in agriculture compared } \\
\text { to the average throughout the } \\
\text { economy; } \\
\text { Profit distribution throughout the } \\
\text { process chain of certain products' } \\
\text { manufacturing }\end{array}$ \\
\hline $\begin{array}{l}\text { Overcoming the natural limitations } \\
\text { for agricultural production }\end{array}$ & $\begin{array}{l}\text { The share of unfavorable territories } \\
\text { among the total of farmlands; } \\
\text { The proportion of productivity in } \\
\text { favorable and unfavorable conditions }\end{array}$ \\
\hline $\begin{array}{l}\text { Social equity, provision of the } \\
\text { conditions for high wages for } \\
\text { agricultural labor }\end{array}$ & $\begin{array}{l}\text { Wage level in agriculture compared } \\
\text { to the average throughout the } \\
\text { economy }\end{array}$ \\
\hline $\begin{array}{l}\text { Support of rural population's activity } \\
\text { and preservation of rural areas }\end{array}$ & $\begin{array}{l}\text { Indicators of natural and migration } \\
\text { dynamics of population; } \\
\text { Living standards of rural population } \\
\text { compared to the average throughout } \\
\text { the economy }\end{array}$ \\
\hline
\end{tabular}

There are several reasons for disagreeing over the choice of the most effective ways to support agricultural players:

- these actions can have different objectives, which require different approaches to the result assessment;

- there is no single approach to selecting the most relevant indicators for an objective and quantitative assessment of the effectiveness of government actions;

- in the case of the implementation of any measures, a large number of factors simultaneously act that significantly distort the achievement of the main objectives.

Meanwhile, it is precisely the formation of uniform approaches to assessing the effectiveness of measures at the state and regional levels in this area that could put an end to these differences. However, so far this has not happened, and it seems that there is no consensus among representatives of the authorities and the academic community even about whether to evaluate only the results of state programs as the most accessible and obvious, or refer to performance indicators.

Methodological and statistical evaluation of the results is much easier. It is expressed, firstly, by the very fact of the movement of the indicators involved towards the target values planned in the framework of state programs, and secondly, by the level of achievement of these values, which can be expressed in fractions, percent, and sometimes in physical terms.

Efficiency involves calculating the quotient of a division, in which, on the one hand, the result is always involved, and on the other, the resources expended in obtaining it (in economics they are estimated in monetary terms, but other options are possible as well).

In order to analyze the economic efficiency of agricultural support measures, it is possible to use the already developed methods and indicators [10], for example, the gross output of farms of all categories for 1 ruble of subsidies or other investments; an increase in profitability indicators per 1 ruble of investments, in particular, profitability of sales and changes in the parameters of companies' debts, as compared to funds allocated under state support measures, and many others. On the other hand, indicators for assessing of the deferred and social efficiency have not yet been so carefully developed in Russian economic literature, and some aspects of these types of efficiency are not currently being quantified at all.

Our study, due to its volume, does not pretend to develop a complete system of indicators for evaluating the effectiveness of budget costs and ongoing activities to support agricultural producers. Moreover, we find it difficult to formulate a sufficiently complete and comprehensive set of indicators to assess the phenomenon of even one of the three types of efficiency identified above. This is due to the following problems in the formation of indicators:

- some types of effect cannot be expressed in monetary form, and sometimes they cannot be quantified at all;

- different sets of factors can influence obtaining the same result in different periods and in different territories, and the degree of influence of each will also vary;

- the indicators should be such that the initial data for their calculation are accessible and reliable, that is, firstly, the costs of the assessment should not become a problem or require the creation of special structures, and secondly, there should be no errors in the calculations that could affect further decision making;

- the source data used to calculate the indicators must characterize exactly the same object.

To overcome all these limitations for a number of indicators that fully and comprehensively characterize at least one of the types of effect for any one enlarged task is so problematic that, in the best case, the development of a system of indicators should become the topic of a full-fledged research conducted by the department of a research institute at a minimum, and in the worst case, it can generally be an insoluble problem.

However, certain conclusions based on available and reliable data can still be drawn. As an example, we can consider two areas of state support for agriculture, 
implemented in the Voronezh region, setting themselves two different tasks.

One direction is aimed at achieving a very specific task, in fact, measured by one quantitative indicator: increasing productivity in dairy cattle breeding in the Voronezh region. The second direction, on the contrary, is the least specific and the broadest in terms of its goals - the development of agricultural sectors. Let us turn to the analysis of the first direction.

For a number of years, substantial resources have been allocated from the budget to increase the milk productivity of cows, and their receipt by dairy farms is reflected in the financial statements, namely in the form of 10-AIC. We intentionally take into account only the assistance received by companies without independent farmers and personal subsidiary plots (Fig. 6), for the same part of the producers we will analyze the results achieved.

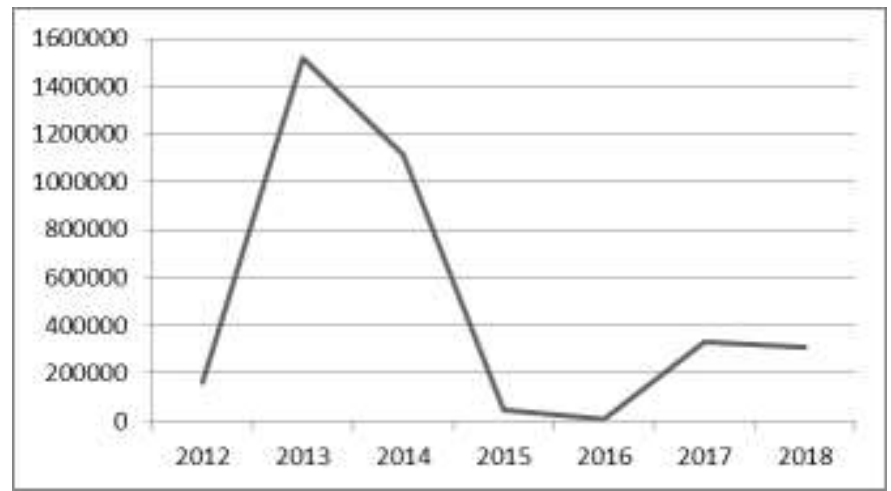

Fig. 6. Subsidies from budgets of different levels to increase the milk productivity of cows for the companies of the Voronezh region

On the graph we see huge amplitude of fluctuations in investment for the purpose we are considering. Such fluctuations are associated not only with budget opportunities, but also with applications received from entrepreneurs. Moreover, if we consider the general trend in the provision of this type of state support, we observe its reduction over the considered time interval.

It seems obvious that investing in the task of increasing milk productivity cannot give immediate returns. Rather, we should expect a time lag of 2-4 years. However, the result should be fixed and further manifest itself without additional financial support. Based on this assumption, in the dynamics of productivity, significant growth can be expected in 2015-2017 with the subsequent maintenance of the achieved level. However, on the graph we see a completely different situation (Fig. 7).

After a certain stagnation in the graph, we observe a progressive, and quite smooth productivity growth, without sharp jumps, and none of the sections of the graph gives us the right to assume that it was the result of a large influx of state subsidies to the industry, noted in 2013.

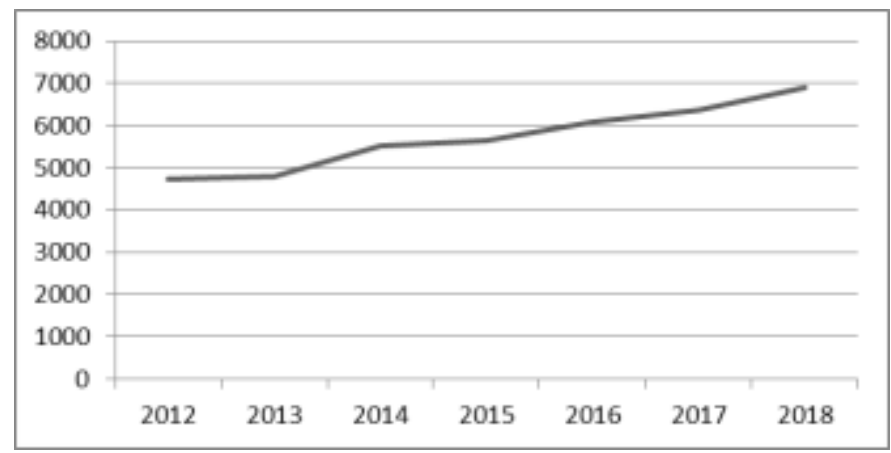

Fig. 7. Dynamics of the milk productivity in the companies of the Voronezh region

Thus, we can point out that, in this particular example, information on the state of affairs in the dairy cattle breeding sector cannot confirm or deny the effectiveness of its support from the federal, regional, and local authorities.

The second of the areas proposed for consideration - the development of agricultural sectors - can no longer be considered on the example of individual groups of agricultural producers. First of all, we evaluate the dynamics of total expenses for this area of state support in the Voronezh region. We already noted above that in the list of target areas of support until 2017, this wording was absent, but several previously applied areas together can be equated to the one under consideration:

- decoupled support for the agricultural producers in crop farming;

- $\quad$ state support of animal husbandry;

- state support of crop farming;

- state support of economically viable regional programs.

Then, taking into account such continuity of directions, the dynamics of support volumes is presented in Figure 8.

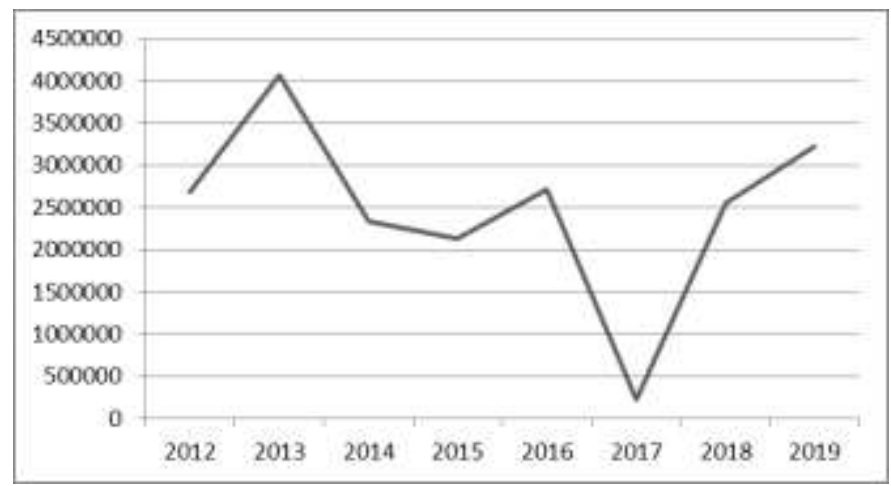

Fig. 8. Dynamics of funding for the development of AIC sectors

However, an important problem is the choice of indicators that can characterize the result of these investments, and they are by no means obvious, so, several approaches to their selection can be proposed.

1. Novikova [11] points to the production of agricultural products as the main goal of providing state support to this sector of the economy. We see a similar approach in 
S.N. Skorikov et al. [12]. Consequently, the measure of the result of such support in its most general form is the dynamics of production volumes, both in crop production (Fig. 9) and in animal husbandry (Fig. 10).

In crop production, we consider it possible to dwell only on the dynamics of growing the major crop groups for the Voronezh region: cereals, sunflowers and sugar beets.

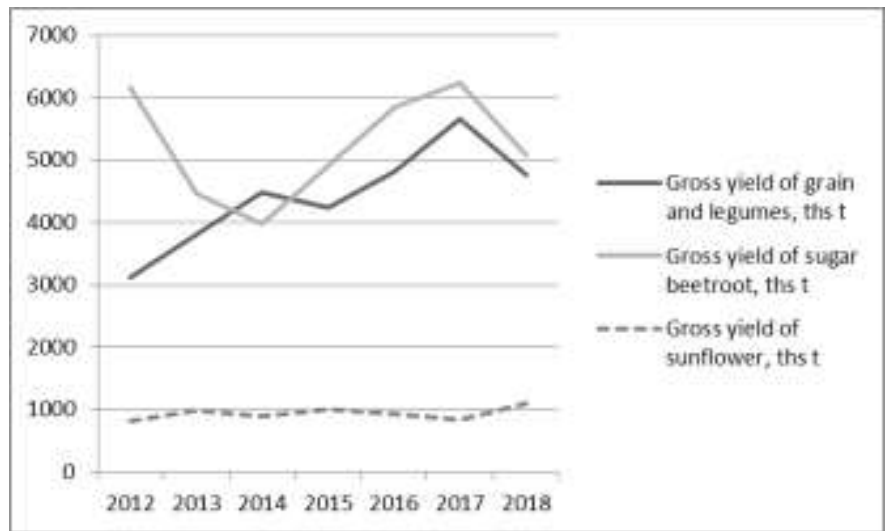

Fig. 9. Dynamics of gross yields of the major crops in the Voronezh region (farms of all categories)

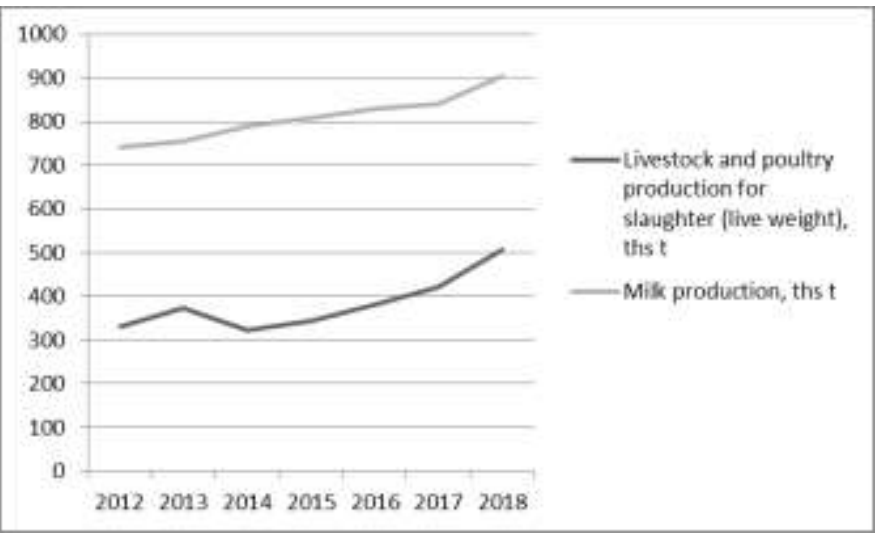

Fig. 10. Dynamics of meat and milk production in the Voronezh region (farms of all categories)

From Figure 9 it is obvious that none of the curves correlates in any way with the curve from Figure 8: neither directly, nor with the lag. The dynamics of sunflower yield is sluggishly growing, cereals - intermittently growing, sugar beet - generally without a pronounced direction of change.

We consider production activities in animal husbandry through the prism of the production of meat of all kinds and milk. In Figure 10, the dynamics of both indicators is quite stable, upward, not showing abrupt changes. The connection with the dynamics of Figure 8 can be conditionally found only in the following form: industry assistance was provided so rationally and efficiently that, despite large fluctuations in the volume of financing, the result was a steadily upward trend in production volumes. However, it is not possible to prove the existence of such an ideal situation by any other means.

2. In the work of Oganyan [13], we see the high importance of such a result of the state support to agriculture, as the amount of resources involved. We do not consider the dynamics of the land fund involved in agricultural production to be considered necessary, since there will be no significant fluctuations in the Voronezh region. Let us consider agricultural machinery as one of the important resources, and trace the dynamics of the number of tractors of all types in the farms of the Voronezh region (Fig. 11).

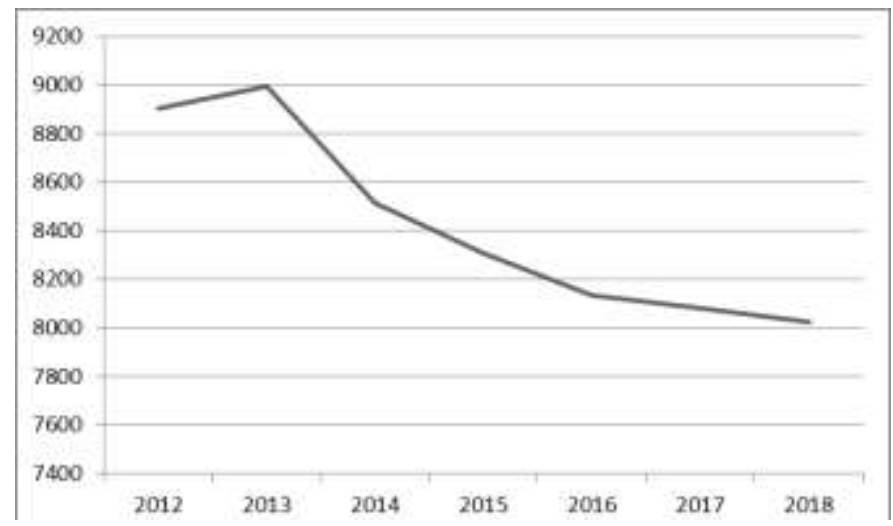

Fig. 11. Dynamics of the number of tractor fleet in all types of farms in the Voronezh region

On the one hand, the observed downward dynamics of the indicator in question in Figure 11 is caused by the purchase of new, and therefore less prone to downtime and breakdowns, as well as more productive tractors and other equipment. On the other hand, these dynamics also does not correlate with that shown in Figure 8, that is, neither the reduction of the tractor fleet, nor their renewal and replacement with modern models can be attributed to the influence of measures to support the agricultural sectors with state support.

3. Neganova and Dudnik [14] note the high importance of the efficiency of capital use by agricultural companies, especially given that the bulk of the support provided to the industry serves precisely the purpose of capital formation and growth. Then one needs to track changes in the return on equity. The data allow calculating it only for the companies in the region without peasant farms. However, this indicator seems to us quite representative, especially when evaluated in dynamics. Bryzgalina [15] recognizes the profitability of production as an important indicator of efficiency. Consider both of these indicators on average for companies of the Voronezh region (Fig. 12).

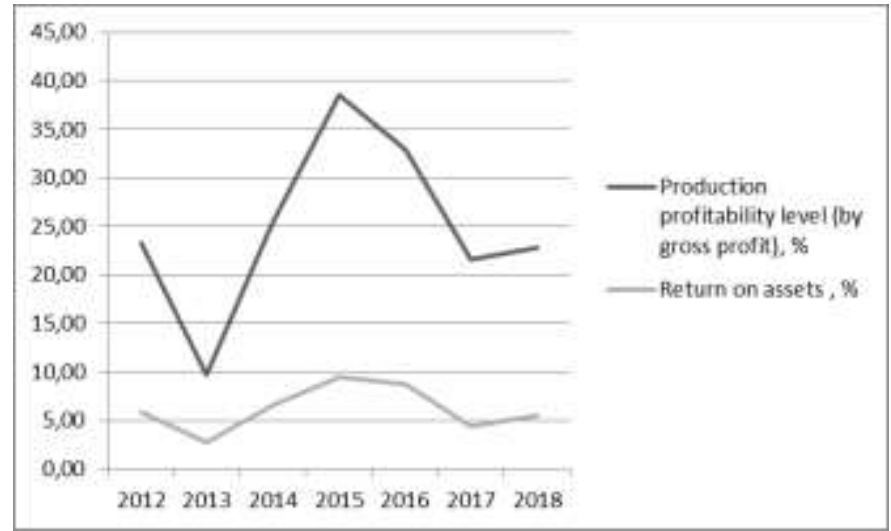

Fig. 12. Dynamics of average return on assets and production profitability level (by gross profit) among agricultural companies of the Voronezh region 
In terms of profitability, one can hardly expect a significant time lag between the receipt of funds and the receipt of the expected financial result. However, it is on this graph that we see the peak of indicators in 2015, that is, two years after the peak of financing in 2013. On the other hand, the minimum profitability of 2017 coincided with the minimum financing of the same year. Thus, here we also cannot prove the existence of a significant relationship between the indicators that make it possible to evaluate the results of state support for the industry and the volume of support itself.

\section{RESULTS}

The agricultural industry is a subsidized sector of the economy, besides, an undoubted fact is that agricultural production in Russia cannot be carried out without significant support from the state. However, the results of government support for Russian agriculture in the main sectors of the industry (crop production, livestock, poultry) has a heterogeneous level of efficiency. For the more rational spending of budgetary funds for the implementation of various measures of the state agricultural policy, it seems important to constantly monitor its effectiveness. For this, in turn, it is necessary to develop a relevant and verifiable procedure, if possible not very laborious, which is a set of performance indicators for different groups of objectives solved with the state support in the agricultural sector.

We believe that the problematic nature of building an integrated system of objective and accessible indicators that would allow evaluation of the results of activities in the field of state support for agriculture has been proven. Also, based on the results of studying academic literature, we are convinced of the absence of a unified procedural approach to the selection and formation of such a system of indicators in the scientific community.

\section{CONCLUSION}

The lack of a recognized procedure (and adopted by the government) for assessing the need for budgetary support for agricultural companies, as well as evaluating the effectiveness of its distribution and application, makes planning and control in this area difficult. As a result, situations of inefficient expense overruns, transfers of assistance to those who may not need it, as well as infusion of funds into those areas where, in principle, they cannot bring the expected impact, are possible.

\section{References}

[1] J.A. Forson, "Innovation financing and public policy dilemmas in the Economic Community of West African States (ECOWAS)", African J. of Sci. Technol. Innovat. \& Development, vol. 12, no. 1, pp. 1-11, 2019.

[2] E.V. Zakshevskaya, S.V. Kuksin, V.V. Stashevskiy, "The priority directions and support of agriculture development in the Voronezh region", pp. 125-127, 2018 [Proc. conf. Urgemt problems of economic development and control of regional economy].

[3] E.V. Gubanova, 'State regulation and support for regional agriculture', Reg. econ.: theory and pract., vol. 51, no. 4, pp. 161-168, 2016.

[4] S. Calatayud Giner, F. D'Amaro, 'Farmers' autonomous management or state regulation? The consolidation of local irrigation associations in Spain (nineteenth to twentieth centuries)", Rural Hist.-Econ. Society Cult., vol. 30, no. 2, pp. 197-213, 2019.

[5] B. Pervaiz, N. Li, M.Q. Manzoor, "Agricultural land use and food security in Pakistan: a structural equation modeling approach", J. of Animal and Plant Sci., vol. 29, no. 5, pp. 1402-1412, 2019.

[6] A. Ruiz-Almeida, M.G. Rivera-Ferre, "Internationally-based indicators to measure Agri-food systems sustainability using food sovereignty as a conceptual framework", Food Security, vol. 11, no. 6, pp. 1321-1337, 2019.

[7] S.W. Wang, B. Manjur, J.-G. Kim, "Assessing Socio-Economic Impacts of Agricultural Subsidies: A Case Study from Bhutan", Sustainability, vol. 11, no. 12, art. 3266, 2019.

[8] I.A. Minakov, V.A. Kuvshinov, "State support of the regional agriculture under the conditions of implementation of the import phaseout strategy", Theory and practice of the global science, no. 3, pp. 14$20,2017$.

[9] A.S. Novikova, "State support of agro-industrial complex in the Tula region", Proc. conf. Sci. issues, pp. 71-79, 2019.

[10] D. Kranjac, K. Zmaic, I. Stefanic et al., "Simulation Of Main Agrarian Policy Indicators Within Beef Meat Market In The Republic Of Croatia By Agmemod Partial Equilibrium Model”, Poljoprivreda, vol. 25, no. 2, pp. 45-51, 2019.

[11] J.Y. Lin, "Structural change and poverty elimination", China Agricult. Econ. Rev., vol. 11, iss. 3(SI), pp. 452-459, 2019.

[12] S.N. Skorikov, E.V. Rodionova, K.V. Smolennikova, E.A. Ulmekalm, "State support of agricultural organizations as a tool of regional AIC strategic management", Global sci. potential, no. 9, pp. 99-100, 2011.

[13] L.R. Oganyan, "Modern tendencies of agriculture development in the stavropol territory", Modern tendencies in the scientific provision of AIC in Verkhnevolzhskiy region, Collective monograph. Suzdal, 2018, pp. 255-263.

[14] V.P. Neganova, A.V. Dudnik, "Improvement of state support for tregional AIC", Reg. econ., vol. 14, no. 2, pp. 651-662, 2018.

[15] M.A. Bryzgalina, "Adaptation of the state support system for cattle breeing companies to the external challenges and limitations", Monograph. Saratov, 2019, 168 p. 